\title{
Okul öncesi dönemdeki çocukların sosyal problem çözme becerilerinin çeşitli değişkenler açısından incelenmesi*
}

\section{Examination of the social problem solving skills of preschool children in terms of various variables}

\author{
Şuheda Bozkurt Yükçü ${ }^{1}$, Haktan Demircioğlu ${ }^{2}$
}

\begin{abstract}
Öz: Bu araştırmanın amacı; okul öncesi dönemdeki çocukların sosyal problem çözme becerilerinin çeşitli değişkenler açısından incelenmesidir. Araştırmanın evreni, 2015-2016 eğitim ve öğretim yılında Ankara ili Çankaya ilçesinde bulunan bağımsız anaokullarına devam eden dört-altı yaş arası çocuklar ve ebeveynlerinden oluşmaktadır. Araştırmanın örneklemi, basit rastgele örnekleme yöntemi ile seçilmiş olan 2015-2016 eğitim ve öğretim yılında Ankara ili Çankaya ilçesinde bulunan bağımsız anaokullarına devam eden dört-altı yaş arası 240 çocuk ve ebeveynden oluşmaktadır. Betimsel araştırma yöntemlerinden kesitsel tarama modelinde yürütülen araştırmanın veri toplama aşamasında; Genel Bilgi Formu ve Wally Sosyal Problem Çözme Dedektiflik Oyun Testi kullanılmıştır. Verilerin analizi yapılırken Kruskal Wallis-H Testi, Bağımsız Gruplar-T Testi ve Tek Yönlü Varyans Analizi kullanılmıştır. Elde edilen bulgulara göre çocukların sosyal problem çözme becerilerinin yaşa göre anlamlı bir farklılık gösterirken; cinsiyete, anne ve baba yaşına, anne ve baba eğitim durumuna, anne ve baba çalışma durumuna, kardeş sayısına ve aylık gelire göre istatistiksel olarak anlamlı bir farklılık göstermemektedir. Araştırma sonuçları ilgili literatür çerçevesinde tartışılmış ve yorumlanmıştır.
\end{abstract}

Anahtar Kelimeler: Okul öncesi, sosyal problem çözme, çocuk gelişimi

\begin{abstract}
The purpose of this research is to examine preschool children's social problem solving skills in terms of various variables. The population of the study consisted of parents and their children between the ages four-six years who attend independent kindergartens located in Çankaya county of Ankara during the 2015-2016 academic year. The sample of the study selected by simple random sampling method, consisted of 240 parents and their children between the ages four-six years who attend independent kindergartens located in Çankaya counties of Ankara during the 2015-2016 academic year. In this study conducted by descriptive screenning model, General Information Form and Wally Child Social Problem Solving Detective Game Test were used. Kruskal Wallis-H Test, Independent Groups T Test, One Way Anova were used to analyze of data. According to the results of this study, social problem solving skills of children differ based on child's age but do not differ based on gender, number of siblings, montly income, parents's age, educational status and working status. The findings were discussed and interpreted within the scope of the literature.
\end{abstract}

Keywords: Preschool, social problem solving, child development

\footnotetext{
${ }^{*}$ Bu çalışma Yrd. Doç. Dr. Haktan Demircioğlu danışmanlığında, Arş. Gör. Şuheda Bozkurt Yükçü’nün Hacettepe Üniversitesi Sağlık Bilimleri Enstitüsü’nde hazırladığı “Bağımsız Anaokullarına Devam Eden Çocukların Duygu Düzenleme ve Sosyal Problem Çözme Becerileri ile Ebeveynlerinin Duygusal okuryazarlık Düzeyleri Arasındaki İlişkinin İncelenmesi” isimli yüksek lisans tezinin bir kısmından üretilmiştir.
}

\footnotetext{
${ }^{1}$ Hacettepe Üniversitesi, Sağlık Bilimleri Fakültesi, Çocuk Gelişimi Bölümü, suhedabzkrt06@gmail.com

${ }^{2}$ Hacettepe Üniversitesi, Sağlık Bilimleri Fakültesi, Çocuk Gelişimi Bölümü, hdemircioglu@hacettepe.edu.tr
} 


\section{SUMMARY}

\section{Introduction}

Interacting and communicating with other individuals in the social environment is one of the most important characteristics of human nature. Encountering some problems in everyday life because of the interaction with the individual's environment is a natural consequence of this feature. Therefore, the individual has to acquire, develop and use problem-solving skills in order to be able to continue their relationship with the social environment in a healthy manner. The basis of this skill, which is quite functional and important in the later years of life, is based on preschool period. For this reason, it is very important to examine the development of social problem solving skills in the preschool period so that healthy social relationships can be established in the future of the individual's life.

\section{Method}

The population of the study consisted of parents and their children between the ages four-six years who attend independent kindergartens located in Çankaya county of Ankara during the 2015-2016 academic year. The sample of the study selected by simple random sampling method, consisted of 240 parents and their children between the ages four-six years who attend independent kindergartens located in Çankaya counties of Ankara during the 2015-2016 academic year. In this study conducted by descriptive screenning model, General Information Form and Wally Child Social Problem Solving Detective Game Test were used. Kruskal Wallis-H Test, Independent Groups T Test, One Way Anova and Pearson's correlation coefficient were used to analyze of data.

\section{Results}

According to the results of this study, social problem solving skills of children differ based on child's age but do not differ based on gender, number of siblings, montly income, parent's age, educational status and working status.

\section{Conclusion and Discussion}

The findings obtained as a result of the research were discussed and interpreted within the scope of the literatüre. The social problem solving abilities of children were examined according to age, gender, number of siblings, montly income, parent's age, educational status and working status and it was found that there was a statistically significant difference only according to the age of the child. When the field literature is examined, it is seen that similar findings are found that social problem solving skills differ according to the age of the child. It is thought that the problem-solving experiences increase with the child's age and this is a natural result. In addition, there is no significant difference in the gender variable when looking at the findings regarding other variables and it seems that this direction differs from the literature. This situation is thought to be related to the changing social structure and having the preschool education. It is thought that the socialization of children without gender discrimination, reduction 
in the gender perspective in the community and in the pre-school education system reduces gender differences in social problem solving skills of children. Similarly, it is thought that having pre-school education may also have an impact in the variable of siblings number. Social problem solving skills of children do not differ based on number of siblings. Another reason for this is the fact that the majority of the children in the sample group have their siblings. It is considered that the age, educational status and working status variables regarding the mother and father may be limited to reveal the differences that may exist due to the sample group. The sampling group studied in the scope of the research shows the characteristics of upper and middle socio-economic level. This situation limits the findings regarding the age, educational status and working status of the parents. It has been seen that social problem solving skills do not differ significantly based on monthly income of the family, unlike the literature. It is thought that this situation may have been caused by the structure of the sampling group as mentioned before. In this direction, it is suggested that the subsequent studies should be conducted with wider sample groups at different socioeconomic status. 


\section{GíRIŞ}

Her kavramın ortaya çıkışından itibaren bir olgunlaşma süreci olduğu gibi sosyal problem çözme kavramı da zaman içerisinde şekillenmiş bir kavramdır. Sosyal problem çözme kavramı ilk olarak 1969 yılında D’Zurilla ve Goldfried (1971) tarafından kullanılmıştır. Ancak alan yazınında kişilerarası problem çözme olarak da ifade edilebilmektedir. Sosyal problem çözme kavramındaki "sosyal” kelimesi problem çözme çalışmalarını herhangi bir problem türüne sınırlandırmak amacıyla değil kişinin gerçek yaşamındaki sosyal çevresi ile uyumunu etkileyen problem çözme becerisi ile ilgilenildiğini vurgulamak amacıyla kullanılmaktadır (D'Zurilla \& Maydeu Olivares, 1995; D'Zurilla, Nezu, \& Maydeu Olivares, 2004). Bu kavram başlangıçta daha çok psikoloji alanında psikolojik ve davranışsal uyum ile bağlantılı olarak araştırılan (D'Zurilla \& Maydeu Olivares, 1995) ve çocukluk döneminin ihmal edildiği bir kavram olsa da zaman içerisinde erken çocukluk dönemini de içine alan bir kavram haline gelmiştir

Sosyal problem çözme becerisi, yaşamın ilk yıllarından itibaren gelişmeye başlayan, özellikle erken dönemde desteklenmesi gereken, ebeveynler ve yakın çevrenin tutum ve becerileri aracılığıyla öğrenilen ve yetişkinliğe kadar gelişmeye devam eden sosyal bir beceri olarak değerlendirilmektedir (Anlıak \& Dinçer, 2005; D'Zurilla, Maydeu Olivares, \& Kant, 1998; D'Zurilla \& Nezu, 1999). Yaşamın ilk yılları olan bebeklik dönemi; gelişimin en yoğun ve hızlı olduğu, bebeklerin dış dünyayı tanıma ve anlama da dahil olmak üzere birçok alanda birincil bakım veren desteğine ihtiyaç duyduğu bir dönemdir. Tüm psikolojik süreçler başlangıçta toplumsal ilişkiler arası etkinliklere gömülüdür ve kişi zaman içerisinde aşamalı olarak bunları kişiselleştirmekte ve içselleştirmektedir (Nelson-Le Gall, 1981). Bu bağlamda düşünüldüğünde çocuklar, ilk problem çözme deneyimlerini ya yetişkin-çocuk etkileşimi sırasında ya da akranları ile deneyimlemektedirler. Başlangıçta problem durumu ile başa çıkmakta başkalarına ihtiyaç duyan çocuk, gelişimsel olarak aşama kaydettikçe problem durumlarını kendi başına çözebilir hale gelmektedir (Nelson-Le Gall, 1981). Tüm bu özellikler sosyal problem çözme becerisinin yaşamın ilk yıllarından başlayarak gelişimsel bir eğri içerisinde ilerlediğine işaret etmektedir.

Sosyal problem çözme için bebeklik döneminde temel oluşturabilecek gelişimsel basamaklar incelendiğinde; Piaget tarafindan duyu motor dönem olarak adlandırılan doğumdan iki yaşa kadar olan sürede sosyal problem çözme becerisine yönelik ilk adımların atıldığı görülmektedir. $\mathrm{Bu}$ dönemde bebeklerin, çevresini duyuları aracılığıyla keşfettiği ifade edilmektedir (San Bayhan \& Artan, 2004). Piaget, bir bebeğin on ikinci ayını tamamladığında bazı problem çözme becerilerini sergilediğini ifade etmektedir. Bebek bu işlemi deneme yanılma yolu ile 
gerçekleştirmektedir. Örneğin bir sopayı uzaktaki bir oyuncağa ulaşmak için kullanabilmektedir (San Bayhan \& Artan, 2004). Bebek on sekiz-yirmi dört aylarına geldiğinde zihinsel fonksiyonları duyu motor düzeyden sembolik düzeye dönüşmektedir. Örneğin, çocuk önceleri kapının önünde duran sandalyeyi devirerek kapıyı açarken artık önce sandalyeyi yoldan kaldırıp daha sonra kapıyı açmaktadır (San Bayhan \& Artan, 2004). İki yaş itibari ile nesne devamlılığının kazanılması ile birlikte çocuk artık basit düzeyde olan deneme yanılma yöntemlerini geliştirerek karşılaştığı problemlere çözüm yolları aramaya çalışmaktadır.

Üç yaşa kadar olan dönemde küçük çocuğun sosyal dünyası, farklı yaşlardaki akranları ve yetişkinlerle zenginleşmekte ve dil gelişimi ile birlikte etkileşime girmeyi gerektiren kişilerarası etkileşim ağları daha karmaşık hale gelmektedir. Bu durum çocuğun sosyal problem durumları ile karşılaşma olasılığını da arttırmaktadır (Ridley \& Vaughn, 1982). Başarılı şekilde kişilerarası ilişkilerin gelişmesi ve sürdürülmesi, sosyal problem çözme becerilerinin kazanımı ve kullanımından etkilenmektedir (D'zurilla \& Goldfried, 1971). Bu nedenle Ridley ve Vaughn'a (1982) göre çocuklar sosyal problem çözmeyi kolaylaştıran becerileri bilmek ve başarılı sosyal problem çözme deneyimlerine ve pratiklerine sahip olmak zorundadırlar. Spivack ve Shure'a (1974) göre sosyal problem çözme becerisinde başarılı olan çocuklar, başarılı olmayan çocuklara göre daha az dürtüsellik ve engellenme gösterirler. Bunun yanı sıra diğerlerinin stres durumlarına karşı daha duyarlıdırlar ve okul öncesi dönemde sosyal problem çözme becerisine sahip olmak, çocuğun ilerleyen yaşamındaki davranışsal uyumunun da belirleyicisidir (Spivack \& Shure, 1974). Sosyal problemlerle nasıl başa çıkacağı öğretilen çocukların sabırsızlık, aşırı duygusallık, agresiflik gibi özellikleri daha azdır; arkadaşları tarafından daha çok sevilirler ve akran ilişkilerinde daha başarılıdırlar (Rooney, Poe, Drescher \& Frantz, 1993; Spivack \& Shure, 1989).

Aynı zamanda önemli bir sosyal beceri olan sosyal problem çözme becerisinin erken dönemde kazanımı; akran kabulü, ebeveyn ve öğretmen tarafından pozitif algılanma, yüksek özgüven gibi pozitif sonuçlara ilişkin başarılı bir döngü geliştirmede de oldukça kritik bir öneme sahiptir (Gesten, Flores de Apodaca, Rains, \& Weissberg, 1979). Bu nedenle sosyal problem çözmede sürekli olarak başarısızlık yaşayan çocukların sosyal izolasyon, akran reddi, okul başarısızlığı gibi problemlerle karşılaşmaları oldukça muhtemeldir (Rubin ve diğ. 1984; Shure, 2001). Okul öncesi dönem çocukları ile yapılan araştırmalarda sosyal problem çözmeye yönelik eğitim verilen ve verilmeyen çocukların sosyal problem çözme becerilerine yönelik belirgin farklılıklar gösterdiği de açık bir şekilde ortaya konmuştur (Casey, 1990; Feis \& Simons, 1985; 
Ridley \& Vaughn, 1982; Sharp, 1981; Shure \& Spivack, 1979, 1982). Bu bulgular sosyal problem çözme becerisi için okul öncesi dönemin kritik bir dönem olduğunu göstermektedir.

Sosyal çevresinde bulunan diğer bireylerle etkileşime girmek ve iletişim kurmak, insan doğasının en önemli özelliklerinden birisidir. Bireyin çevresi ile olan etkileşimi nedeniyle günlük yaşamda bazı problemlerle karşılaşması ise bu özelliğinin doğal bir sonucudur. Dolayısıyla birey, sosyal çevresi ile olan ilişkilerini sağlıklı bir şekilde devam ettirebilmek için problem çözme becerisini edinmek, geliştirmek ve kullanmak zorundadır. Yaşamın ileriki yıllarında oldukça işlevsel ve önemli olan bu becerinin temelleri ise okul öncesi döneme dayanmaktadır. $\mathrm{Bu}$ nedenle; sosyal problem çözme becerilerinin gelişimini okul öncesi dönemde incelemek, bireyin yaşamının ileriki dönemlerinde sosyal hayatını sağlıklı bir şekilde devam ettirebilmesi için oldukça önemlidir.

Okul öncesi dönemde sosyal becerilerin kazanılmasında çocuğun ailesi ve akranları ile kurmuş olduğu ilişkiler, oyun ve eğitim kurumları oldukça önemlidir (Chen \& Rubin, 1992; Gülay \& Akman, 2009; Paswan, Sanjeev, \& Bansal, 2014; Rubin, Daniels-Beirness, \& Bream, 1984). Kasik'e (2011) göre aile yapısı ve kişinin bu yapı içerisindeki konumu, çocukluk ve ergenlik dönemi boyunca sosyal problem çözme becerisinin gelişimini etkileyen önemli bir faktördür. Yapılan araştırmalarda sosyal problem çözme becerisinin gelişiminde aile içi etkileşimlerin (ebeveyn-çocuk ve çocuk-çocuk arası) ve anne ve baba tarafindan model olunan problem çözme stratejilerinin güçlü bir belirleyici olduğu ifade edilmektedir (Keltikangas-Jarvinen, 2005; Pakaslahti, Karjalainen \& Keltikangas-Jarvinen, 2002). Aile içerisinde problem yaşayan çocuklar okul akranlarına göre daha düşük sosyal problem çözme becerisine sahiptirler (Perez ve diğ.,1981). Bunun yanı sıra ebeveynin kullandığı problem çözme teknikleri (eğitim düzeyinden etkilenen) ve ebeveynin aile serbest zaman aktiviteleri boyunca davranışları çocuğun sosyal problem çözme becerisinin gelişiminde oldukça önemlidir (Cartıllı \& Bedel, 2015; Kasik, 2011). Bu doğrultuda araştırmanın amacı bağımsız anaokullarına devam eden dört-altı yaş arası çocukların sosyal problem çözme becerilerini çeşitli değişkenler açısından incelemektir. Bu amaca yönelik araştırma soruları ise şunlardır:

1. Çocukların sosyal problem çözme becerileri yaşa göre farklılaşmakta mıdır?

2. Çocukların sosyal problem çözme becerileri cinsiyete göre farklılaşmakta mıdır?

3. Çocukların sosyal problem çözme becerileri anne ve babanın yaşına göre farklılaşmakta midir?

4. Çocukların sosyal problem çözme becerileri anne ve babanın eğitim durumuna göre farklılaşmakta mıdır? 
5. Çocukların sosyal problem çözme becerileri anne ve babanın çalışma durumuna göre farklılaşmakta mıdır?

6. Çocukların sosyal problem çözme becerileri ailenin aylık gelir durumuna göre farklılaşmakta mıdır?

7. Çocukların sosyal problem çözme becerileri kardeş sayısına göre farklılaşmakta mıdır?

\section{YÖNTEM}

Bu araştırmada bağımsız anaokullarına devam eden çocukların sosyal problem çözme becerileri çeşitli değişkenler açsından incelenmiştir. $\mathrm{Bu}$ amaçla betimsel araştırma yöntemlerinden kesitsel tarama modeli kullanılmıştır (Büyüköztürk, Çakmak, Akgün, Karadeniz, \& Demirel, 2008).

\section{Evren ve Örneklem}

Araştırma evrenini, 2015-2016 eğitim öğretim yılında Ankara ilinin Çankaya ilçesinde bulunan 16 bağımsız anaokuluna devam eden dört-altı yaş arası 1613 çocuk ve ebeveyni oluşturmaktadır. Araştırmanın evren bilgilerine MEBBİS veri tabanı aracılığıyla ulaşılmıştır. Araştırma örneklemini ise basit rastgele örnekleme yöntemiyle seçilen, 2015-2016 eğitim öğretim yılında Ankara ilinin Çankaya ilçesinde bulunan 13 bağımsız anaokuluna devam etmekte olan dört-altı yaş arası 111'i kız ve 129'u erkek olmak üzere toplam 240 çocuk ve ebeveyni oluşturmaktadır. Araştırmanın örneklem büyüklüğü belirlenirken Israel (1992) tarafından örneklem büyüklüğü hesaplama formülleri kullanılarak hazırlanmış olan örneklem büyüklüğü belirleme tablosu kullanılmıştır. Araştırma kapsamında örneklemin evreni temsiliyetini arttırmak amaciyla, evrende bulunan tüm okullardan veri toplanması amaçlanmıştır. Bu doğrultuda kurum yetkilileri tarafından veri toplanmasına izin verilmeyen üç okul dışında 13 bağımsız anaokulunda veri toplama işlemi gerçekleştirilmiştir. Araştırmanın örneklem grubuna ilişkin demografik dağılımlar ise Tablo 1'de verilmiştir.

Tablo 1. Araştırmaya katılan çocuklar ve ebeveynlerine ilişkin demografik özelliklerin dă̆llımı.

\begin{tabular}{|c|c|c|c|c|}
\hline & Değişkenler & Gruplar & $\mathbf{F}$ & $\%$ \\
\hline \multirow{11}{*}{ Çocuklar } & \multirow{2}{*}{ Cinsiyet } & $\mathrm{K} 1 \mathrm{Z}$ & 111 & 46,2 \\
\hline & & Erkek & 129 & 53,8 \\
\hline & \multirow{3}{*}{ Yaş } & 4 & 99 & 41,3 \\
\hline & & 5 & 128 & 53,3 \\
\hline & & 6 & 13 & 5,4 \\
\hline & \multirow{3}{*}{ Kardeş Sayısı } & Kardeşi yok & 59 & 24,6 \\
\hline & & Bir kardeş & 152 & 63,3 \\
\hline & & İki kardeş ve üzeri & 29 & 12,1 \\
\hline & \multirow{3}{*}{ Eğitim } & Ortaokul ve öncesi & 27 & 11,3 \\
\hline & & Lise & 78 & 32,5 \\
\hline & & Üniversite & 115 & 47,9 \\
\hline
\end{tabular}




\begin{tabular}{|c|c|c|c|c|}
\hline \multirow{10}{*}{ Anne } & & Yüksek lisans-Doktora & 20 & 8,3 \\
\hline & \multirow{4}{*}{ Yaş } & $21-30$ yaş arası & 46 & 19,2 \\
\hline & & $31-35$ yaş arası & 84 & 35,0 \\
\hline & & $36-40$ yaş arası & 80 & 33,3 \\
\hline & & 41 yaş ve üzeri & 30 & 12,5 \\
\hline & \multirow{5}{*}{ Çalışma Durumu } & Çalışmıyor & 105 & 43,8 \\
\hline & & Kamu Görevlisi & 63 & 26,3 \\
\hline & & İşçi & 16 & 6,7 \\
\hline & & Serbest Meslek & 25 & 10,4 \\
\hline & & Özel Sektör & 31 & 12,9 \\
\hline \multirow{11}{*}{ Baba } & \multirow{4}{*}{ Eğitim } & Ortaokul ve öncesi & 26 & 10,8 \\
\hline & & Lise & 71 & 29,6 \\
\hline & & Üniversite & 119 & 49,6 \\
\hline & & Yüksek lisans-Doktora & 24 & 10,0 \\
\hline & \multirow{3}{*}{ Yaş } & $26-35$ yaș aras1 & 82 & 34,2 \\
\hline & & $36-40$ yaş arası & 82 & 34,2 \\
\hline & & 41 yaş ve üzeri & 76 & 31,7 \\
\hline & \multirow{4}{*}{ Çalışma durumu } & Kamu Görevlisi & 77 & 32,1 \\
\hline & & İşçi & 43 & 17,9 \\
\hline & & Serbest Meslek & 85 & 35,4 \\
\hline & & Özel Sektör & 35 & 14,6 \\
\hline \multirow{6}{*}{ Aile } & \multirow{6}{*}{ Aylık Gelir } & $949-1500 \mathrm{TL}$ & 24 & 10,0 \\
\hline & & $1501-3000 \mathrm{TL}$ & 54 & 22,5 \\
\hline & & $3001-4500 \mathrm{TL}$ & 59 & 24,6 \\
\hline & & $4501-6000 \mathrm{TL}$ & 55 & 22,9 \\
\hline & & 6001 TL ve üzeri & 48 & 20,0 \\
\hline & & Toplam & 240 & 100 \\
\hline
\end{tabular}

\section{Veri Toplama Araçları}

Araştırmaya ilişkin verilerin toplanması amacıyla; araştırmaya katılan çocuk ve anne-babasına ilişkin genel bilgileri elde etmek amacıyla araştırmacı tarafından hazrılanan Genel Bilgi Formu ve çocukların sosyal problem çözme becerilerini ölçmek amaciyla Wally Sosyal Problem Çözme Dedektiflik Oyun Testi (WSPÇDOT) kullanılmıştır.

\section{Genel Bilgi Formu}

Araştırma kapsamına alınan çocuklar ve ebeveynleri hakkında bilgi elde etmek amcıyla araştırmacı tarafından on iki maddeden oluşan genel bilgi formu hazırlanmıştır. Bu formda: çocuğun yaşı, cinsiyeti ve kardeş sayısı; anne-babanın yaşı, eğitim durumları ve çalışma durumları ve ailenin aylık gelir durumuna ilişkin bilgileri ortaya koymaya yönelik maddeler bulunmaktadır. Bu form, bağımısız anaokulları aracılığıyla ebeevynlere gönderilmiş ve anne ya da babanın doldurması istenmiştir. Formlar ebeveynler tarafından bağımsız anaokullarına teslm edilmiş ve araştırmacı kurumdan teslim almıştır.

Wally Çocuk Sosyal Problem Çözme Dedektiflik Oyun Testi (WÇSPÇDOT) (Wally Child Social Problem Solving Detective Game Test) 
Bu ölçek Webster-Stratton (1990) tarafindan, Spivak ve Shure'un (1985) Preschool Problem Solving Test ve Rubin ve Krasnor'un (1986) Child Social Problem-Solving Test ölçeklerinden yararlanılarak geliştirilmiştir. Ölçek çocukların sosyal problem çözme becerilerinin hem nitelik hem de niceliğini ölçmektedir. Ölçek, 15 farklı varsayımsal problem durumlarına yönelik resimli hikayelerden oluşmakta ve kız ve erkek formu olmak üzere iki ayrı formu bulunmaktadır. Ölçekte, çocuğa sosyal problemleri içeren hikayeler resimler aracılığıyla sunulmakta ve çocuktan her problemi kendi ifadeleri ile cevaplaması istenmektedir. Çocuğun problem durumuna ilişkin vermiş olduğu her cevap uygulamacı tarafindan yazılı olarak kaydedilmektedir. Araştırmacı tarafından kaydedilen cevaplar testin puanlama yönergesine göre pozitif $(\mathrm{P})$, negatif $(\mathrm{N})$ ve puanlanmaz (boş) olarak puanlanmaktadır. Çocuğun aldığı her pozitif sonuca bir (1) puan, negatif ya da puanlanamaz sonucuna ise sıfır (0) puan verilmektedir. Çocuğun bu testten aldığı en düşük puan sıfır (0), en yüksek puan ise on beş (15)'dir. Yüksek puan yüksek sosyal problem çözme becerisine, düşük puan ise düşük sosyal problem çözme becerisine işaret etmektedir.

Wally Çocuk Sosyal Problem Çözme Dedektif Oyun Testi'nin orjinal çalışmasında prososyal çözüm kategorileri için iç tutarlılık katsayısı Cronbach Alpha değeri .65, antisosyal çözüm kategorileri için .64 bulunmuştur. Testin yapı geçerliği Wally Çocuk Sosyal Problem Çözme Dedektif Oyun Ölçeği ile Rubin ve Krasnor'un Çocuk Sosyal Problem Çözme ölçeği ile sınanmıştır. Prososyal stratejileri arasındaki korelasyon katsayısı $(\mathrm{r}=.60)$, antisosyal stratejiler arasındaki korelasyon katsayısı $(\mathrm{r}=.50)$ bulunmuştur.

Testin Türkçe uyarlaması ilk olarak Dereli (2013) tarafından altı yaş çocukları için yapılmıştır. Yılmaz (2012) tarafindan yapılan uyarlama çalışmasında ise ölçek 60-72 aylık çocuklar için uyarlanmış ve KR- 20 güvenirlik katsayısı .79 olarak geçerli ve güvenilir olarak bulunmuştur. Testin üç-beş yaş için uyarlama çalışması ise Kayılı ve Arı (2015) tarafından yapılmış ve üç yaş çocukları için güvenirlik katsayısı $.72(n=50)$, dört yaş çocukları için $.79(n=145)$, beş yaş çocukları için .81 $(\mathrm{n}=504)$ olarak hesaplanmıştır. Elde edilen araştırma sonuçlarına göre güvenirliği ortaya konmuştur.

Testin Türkçe uyarlaması ilk olarak Dereli (2013) tarafından 6 yaş çocukları için yapılmıştır. Yılmaz (2012) tarafından yapılan uyarlama çalışmasında ise ölçek 60-72 aylık çocuklar için uyarlanmış ve $\mathrm{Kr} 20$ güvenirlik katsayısı .79 olarak geçerli ve güvenilir olarak bulunmuştur. Testin 3-5 yaş için uyarlama çalışması ise Kayılı ve Arı (2015) tarafından yapılmış ve üç yaş çocukları için güvenirlik katsayısı $.72(n=50)$, dört yaş çocukları için .79 $(n=145)$, beş yaş 
çocukları için .81 $(\mathrm{n}=504)$ olarak hesaplanmıştır. Elde edilen araştırma sonuçlarına göre güvenirliği ortaya konmuştur.

\section{Veri Toplama İşlemi}

Araştırmanın veri toplama aşamasında ilk olarak Çankaya ilçesinde bulunan MEB'e bağlı 13 bağımsız anaokuluna gidilerek anne-babalara ulaştırılmak üzere Genel Bilgi Formu ve Gönüllü Katılım Formu öğretmenlere verilmiştir. İkinci aşamada, anne-babalardan formların dönüşleri alınmış ve araştırma kapsamına alınmasına ebeveynleri tarafından onay verilen çocuklara bireysel olarak Wally Sosyal Problem Çözme Dedektiflik Oyun Testi uygulanmıştır. Uygulama sırasında çocuk ve araştırmacının yalnız olduğu bir ortamda 15 farklı problem durumunu içeren 15 farklı resim sırası ile çocuğa sözlü ve görsel olarak sunulmuş ve çocuğun problem durumuna vermiş olduğu cevaplar yazılı olarak kaydedilmiştir. Bu işlem her bir çocuk için 5 ile 10 dakika arasında sürecek şekilde 240 çocuk için tamamlanmıştır. Veri toplama işlemi dört ay içerisinde tamamlanmıştır.

\section{Verilerin Analizi}

Wally Sosyal Problem Çözme Dedektiflik Oyun Testi ve Genel Bilgi Formu aracılı̆̆ıyla elde edilen veriler bilgisayar ortamına aktarılarak Sosyal Bilimler İçin İstatistik Programı (SPSS 20.00) ile değerlendirilmiştir. Verilerin analizinde kullanılacak yöntemlerin belirlenmesi amacıyla verilen normal dağılıma uygunluğu Kolmogorov-Smirnov testi ile kontrol edilmiştir. Buna göre ölçek toplam puan normallik varsayımını sağlanmadığı $(\mathrm{p}=.000<.050)$ sonucuna varılmıştır. Ancak Merkezi Limit Teoremi’ne göre belirli bir evrenden rastgele bir örneklem seçildiğinde, çekilen örneklem sayısı büyüdükçe verilerin normal dağılıma yaklaştığı varsayılmaktadır (Field, 2009). Yani örneklem sayısının yeterince büyük olduğu durumlarda bu teoreme göre parametrik testler tercih edilmektedir. Bu nedenle çocukların yaş dağglımındaki altı yaş çocuklarının sayısının 13 olması (Bkz; Tablo 1) sebebi ile yaş değişkeni için nonparametrik testler tercih edilmiş ve diğer değişkenler için parametrik testler tercih edilmiştir. Yapılan istatistiksel analizler sırasında gruplar arasındaki farklılıklar belirlenirken ikili karşılaştırmalarda parametrik testlerden Bağımsız Gruplar T Testi; çoklu karşılaştırmalarda ise parametrik testlerden Tek Yönlü Varyans Analizi (ANOVA) ve nonparametrik testlerden Kruskal Wallis-H Testi kullanılmıştır. Tek Yönlü Varyans Analizi (ANOVA) sonuçlarında anlamlı bir farklılığın görülmesi durumunda farkın hangi gruplar arasında meydana geldiğini ortaya koymak amacıyla Post-Hoc Çoklu Karşılaştırma Test'lerinden Bonferoni Testi kullanılmıştır. Yapılan istatistiksel analizlerde anlamlılık düzeyi .05 olarak belirlenmiştir. 


\section{BULGULAR}

Bu bölümde araştırmanın problemlerine yönelik olarak yapılan istatistiksel analiz bulgularına yer verilmiştir. İlk olarak araştırmaya katılan çocukların Wally Sosyal Problem Çözme Dedektiflik Oyun Testi ölçeğinden almış oldukları puanlara yönelik ortalama, standart sapma, minimum ve maksimum puanlar Tablo 2'de verilmiştir.

Tablo 2. Wally sosyal problem çözme dedektiflik oyun testi'nden elde edilen puanların betimsel istatistikleri

\begin{tabular}{lccccc}
\hline \multicolumn{1}{c}{ Ölçek } & n & $\overline{\boldsymbol{x}}$ & Min & Max & ss \\
\hline $\begin{array}{l}\text { Wally Sosyal Problem } \\
\text { Çözme Dedektiflik Oyun }\end{array}$ & 240 & 10.8 & 0 & 15 & 3.42 \\
\begin{tabular}{l} 
Testi (WSPÇDOT) \\
\hline
\end{tabular} & & & & & \\
\hline
\end{tabular}

Tablo 2'ye göre, araştırmaya katılan çocukların "Wally Sosyal Problem Çözme Dedektiflik Oyun Testi”nden almış oldukları toplam puan ortalamaları $10.8( \pm 3.42)$ dir. Ölçekten elde edilebilecek olan maksimum puanın 15 olduğu düşünüldüğünde çocukların puan ortalamalarının oldukça yüksek olduğunu söylemek mümkündür.

Tablo 3. Çocukların wally sosyal problem çözme dedektiflik oyun testi toplam puanlarının çocukların yaşlarına göre farklılı̆̆ına ilişkin kruskal wallis h testi sonuçları

\begin{tabular}{llcccccc}
\hline Ölçek & Yaş & $\mathbf{N}$ & $\begin{array}{c}\text { Sıra } \\
\text { ort. }\end{array}$ & sd & $\chi^{\mathbf{2}}$ & $\mathbf{p}$ & Anlamlı Fark \\
\hline Wally Sosyal & 1) 4Yaş & 99 & 96.88 & & & & \\
Problem Çözme & 2) 5Yaş & 128 & 136.79 & 2 & 19.7 & $\mathbf{0 . 0 0}$ & $\mathbf{1 - 2}$ \\
$\begin{array}{l}\text { Dedektiflik Oyun } \\
\text { Testi }\end{array}$ & 3) 6Yaş & 13 & 139.96 & & & & \\
\hline
\end{tabular}

Tablo 3'e göre, çocukların wally sosyal problem çözme dedektiflik oyun testinden almış oldukları toplam puanlar, çocukların yaşlarına göre istatistiksel olarak anlamlı bir şekilde farklılaşmaktadır $(\mathrm{p}=.00<.05)$. Bu farkın hangi gruplar arasında meydana f-geldiğini ortaya koymak amacıyla Post-Hoc testlerinden Bonferroni Testi uygulanmış ve 4 yaş ile 5 yaş arasında istatistiksel olarak anlamlı bir farklılık olduğu bulunmuştur. Çocukların yaşı arttıkça Wally Sosyal Problem Çözme Dedektiflik Oyun Testi’nden almış oldukların arttığı söylenebilir.

Tablo 4. Çocukların wally sosyal problem çözme dedektiflik oyun testi toplam puanlarının çocukların cinsiyetine göre farklılı̆̆ına ilişkin t-testi sonuçları

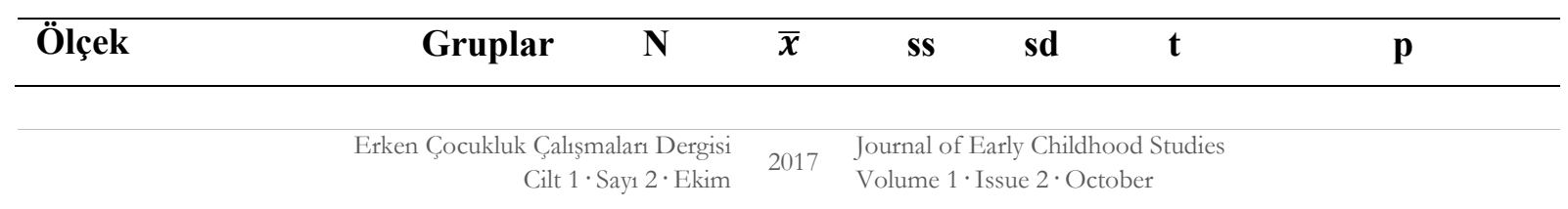




\begin{tabular}{llllllll}
\hline Wally Sosyal Problem & & & & & & & \\
Çözme Dedektiflik & Erkek & 111 & 10.84 & 3.55 & & \\
Oyun Testi & K1z & 129 & 10.98 & 3.50 & 238 & -0.30 & 0.76 \\
\hline
\end{tabular}

Tablo 4'e göre, çocukların wally sosyal problem çözme dedektiflik oyun testinden almış oldukları toplam puanlar, çocukların cinsiyetine göre istatistiksel olarak anlamlı bir farklılık göstermemektedir $(\mathrm{p}=.76>.05)$.

Tablo 5. Çocukların wally sosyal problem çözme dedektiflik oyun testi toplam puanlarının annenin ve babanın yaşına göre farklılı̆̆ına ilişkin tek yönlü varyans analizi (anova) sonuçları

\begin{tabular}{lllclll}
\hline Değişkenler & Gruplar & $\mathbf{n}$ & $\overline{\boldsymbol{x}}$ & $\mathbf{S s}$ & $\mathbf{F}$ & $\mathbf{p}$ \\
\hline \multirow{3}{*}{ Anne Yaş } & $21-30$ yaş & 46 & 11.04 & 3.03 & & \\
& $31-35$ yaş & 84 & 10.46 & 3.55 & 1.04 & 0.37 \\
& $36-40$ yaş & 80 & 11.41 & 3.68 & & \\
& 41 yaş + & 30 & 10.70 & 3.67 & & \\
Baba Yaş & 26-35 yaş & 82 & 10.78 & 3.08 & & \\
& 36-40 yaş & 82 & 11.06 & 3.61 & 0.12 & \\
& 41 yaş + & 76 & 10.92 & 3.89 & & \\
\hline
\end{tabular}

Tablo 5'e göre, çocukların wally sosyal problem çözme dedektiflik oyun testinden almış oldukları toplam puanlar, annenin yaşına göre $(p=.37>.05)$ ve babanın yaşına $(p=.87>.05)$ göre istatistiksel olarak anlamlı bir farklılık göstermemektedir.

Tablo 6. Çocukların wally sosyal problem çözme dedektiflik oyun testi toplam puanlarının annenin ve babanın eğitim durumuna göre farklılı̆̆ına ilişskin tek yönlü varyans analizi (anova) sonuçları

\begin{tabular}{lllclll}
\hline Değişkenler & Gruplar & $\mathbf{n}$ & $\overline{\boldsymbol{x}}$ & ss & $\mathbf{F}$ & $\mathbf{p}$ \\
\hline \multirow{3}{*}{ Anne Eğitim } & Ortaokul ve öncesi & 27 & 11.66 & 3.72 & & \\
Durumu & Lise & 78 & 10.88 & 3.39 & 0.48 & 0.69 \\
& Lisans & 115 & 10.75 & 3.60 & & \\
& Lisansüstü & 20 & 11.00 & 3.40 & & \\
Baba Eğitim & Ortaokul ve öncesi & 26 & 11.38 & 3.28 & & \\
Durumu & Lise & 71 & 11.00 & 3.91 & 0.47 & \\
& Lisans & 119 & 10.68 & 3.41 & & \\
& Lisansüstü & 24 & 11.16 & 3.39 & & \\
\hline
\end{tabular}

Tablo 6'ya göre, çocukların wally sosyal problem çözme dedektiflik oyun testinden almış oldukları toplam puanlar, annenin eğitim düzeyine göre $(p=.69>.05)$ ve babanın eğitim düzeyine $(\mathrm{p}=.75>.05)$ göre istatistiksel olarak anlamlı bir farklılık göstermemektedir. 
Tablo 7. Çocukların wally sosyal problem çözme dedektiflik oyun testi toplam puanlarının annenin ve babanın çalışma durumuna göre farklılı̆̆ına ilişkin tek yönlü varyans analizi (anova) sonuçları

\begin{tabular}{lllclll}
\hline Değişkenler & Gruplar & $\mathbf{N}$ & $\overline{\boldsymbol{x}}$ & $\mathbf{s s}$ & $\mathbf{F}$ & $\mathbf{p}$ \\
\hline \multirow{3}{*}{ Anne Çalışma } & Çalışmıyor & 105 & 10.83 & 3.49 & & \\
Kurumu & Kamu Görevlisi & 63 & 10.84 & 3.65 & & 0.20 \\
& İşçi & 16 & 11.75 & 3.49 & 1.49 & \\
& Serbest Meslek & 25 & 9.76 & 3.95 & & \\
& Özel Sektör & 31 & 11.87 & 2.82 & & \\
Baba Çalışma & Kamu Görevlisi & 77 & 10.94 & 3.93 & & \\
Durumu & İşçi & 43 & 11.55 & 2.35 & 0.99 & \\
& Serbest Meslek & 85 & 10.47 & 3.61 & & \\
& Özel Sektör & 35 & 11.17 & 3.55 & & \\
\hline
\end{tabular}

Tablo 7'ye göre, çocukların wally sosyal problem çözme dedektiflik oyun testinden almış oldukları toplam puanlar, annenin çalışma durumuna $(\mathrm{p}=.20>.05)$ ve babanın çalışma durumuna ( $\mathrm{p}=.39>.05)$ göre istatistiksel olarak anlamlı bir farkl1lık göstermemektedir.

Tablo 8. Çocukların wally sosyal problem çözme dedektiflik oyun testi toplam puanlarının kardeş sayısına ve aylık gelir durumuna göre farklılığına ilişkin tek yönlü varyans analizi (anova) sonuçları

\begin{tabular}{llccccc}
\hline Değişkenler & Gruplar & $\mathbf{n}$ & $\overline{\boldsymbol{x}}$ & ss & F & p \\
\hline \multirow{3}{*}{ Kardeş Sayıs1 } & Kardeş yok & 59 & 10.81 & 3.86 & & \\
& Bir kardeş & 152 & 10.95 & 3.28 & 0.03 & 0.96 \\
& İki kardeş ve üzeri & 29 & 10.96 & 4.11 & & \\
\hline \multirow{3}{*}{ Aylık Gelir } & 949-1500 TL & 24 & 10.08 & 4.06 & & \\
& 1501-3000 TL & 54 & 11.35 & 3.57 & & \\
& 3001-4500 TL & 59 & 10.40 & 3.39 & 1.01 & \\
& 4501-6000 TL & 55 & 11.25 & 3.24 & & \\
& 6000TL ve + & 48 & 11.10 & 3.64 & & \\
\hline
\end{tabular}

Tablo 8'e göre, çocukların wally sosyal problem çözme dedektiflik oyun testinden almış oldukları toplam puanlar, kardeş sayısına $(p=.96>.05)$ ve aylık gelire $(p=.40>.05)$ göre istatistiksel olarak anlamlı bir farklılık göstermemektedir.

\section{SONUÇLAR ve TARTIŞMA}

Sosyal problem çözme becerisi, yaşamın ilk yıllarından itibaren gelişmeye başlayan, özellikle erken dönemde desteklenmesi gereken, tutum ve beceriler aracılığıyla öğrenilen ve yetişkinliğe kadar gelişmeye devam eden bir beceri olarak değerlendirilmektedir (Anliak \& Dinçer, 2005; D'Zurilla et al., 1998; D'Zurilla \& Nezu, 1999). Bu nedenle okul öncesi dönemde sosyal problem çözme becerisini kazanmak da çocuk için oldukça önemlidir. 
Araştırma sonuçlarına göre çocukların sosyal problem çözme becerileri yaşa göre anlamlı bir farklılık göstermektedir (Arı \& Yaban 2012; Bal \& Temel, 2014; Çam \& Tümkaya 2006; Güneysu, Dinçer \& Etikan 1997; Yaban \&Yükselen 2007; Y1lmaz \& Tepeli, 2013). Bu araştırma sonucunda yaş değişkenine yönelik söz konusu farklılık dört ve beş yaş arasında meydana gelmekte ve sosyal problem çözme becerisi çocuğun yaşı arttıkça artmaktadır. $\mathrm{Bu}$ sonuç ilgili literatürü destekler niteliktedir. Sosyal problem çözme becerisi hem sosyal gelişim hem de bilişsel gelişim temelinde şekillenmektedir. Dolayısıyla yaş ile birlikte bu alanlarda meydana gelen gelişimsel ilerlemeyi aynı şekilde sosyal problem çözme becerisinde görmek oldukça anlamlı bir sonuçtur. Bunun yanı sıra çocuğun yaşı ile birlikte yaşamış olduğu sosyal problem çözme deneyimleri de artış göstermektedir. Çocuğun karşılaşmış olduğu her sosyal problem çözme deneyimi bir sonraki problem durumu için temel oluşturması bakımından bu becerinin yaş ile birlikte artması oldukça muhtemel ve istenen bir durumdur. Çocukların sosyal problem çözme becerilerinin yaşa göre farklılı̆ğ incelenirken altı yaş grubu çocuklar ile dört ve/veya beş yaş grubu çocuklar arasında herhangi bir farklılı̆̆a rastlanmamıştır. Örneklem grubunun yaş dağılımı göz önüne alındığında (Bkz; Tablo 1) bu durum beklenilen bir sonuçtur. Altı yaş grubu çocukların büyük çoğunluğunun ilköğretim birinci sınıfa başlıyor olması, okul öncesi eğitim kurumlarında altı yaş grubu çocukların sayısını azaltımıştır. Milli Eğitim Bakanlığı Bilgi Sistemi’nden elde edilen bilgiye göre çalışılan evrende bulunan altı yaş grubu çocuk sayısı 24'tür. Bu nedenle örneklem grubu altı yaş çocukları ile dört ve/veya beş yaş grubu arasındaki farklılıkları ortaya koymaya elverişli değildir.

Sosyal problem çözme becerisinin yaşa göre değişimine yönelik literatür incelendiğinde, bu becerinin yaş ile birlikte geliştiği konusunda ortak bir kanıya varıldığı görülmektedir. Bal ve Temel (2014) tarafından dört-altı yaş arası okulöncesi eğitim kurumuna devam eden çocukların kişilerarası problem çözme becerileri ile bakış açısı alma becerileri arasındaki ilişkiyi incelemek amacıyla yapılan araştırmada, dört yaşındaki çocukların kişilerarası problem çözme becerilerinin beş ve altı yaşındaki çocuklardan anlamlı şekilde farklılaştığı ortaya konmuştur. Benzer şekilde Yılmaz ve Tepeli (2013) tarafından 60-72 aylık çocukların sosyal problem çözme becerilerinin duyguları anlama becerileri açısından incelendiği araştırmada 67-72 aylık çocukların 60-66 aylık çocuklardan daha yüksek düzeyde sosyal problem çözme becerisine sahip oldukları bulunmuştur. Benzer şekilde birçok araştırma bu araştırma sonucunu destekler niteliktedir (Arı \& Yaban 2012; Bal \& Temel, 2014; Çam \& Tümkaya 2006; Güneysu, Dinçer \& Etikan 1997; Yaban \&Yükselen 2007; Y1lmaz \& Tepeli, 2013). 
Benzer şekilde Rubin ve Krasnor (1983) tarafından okulöncesi ve anasınıfı çocuklarında hipotetik sosyal problemlerde yaş ve cinsiyet farklılıklarını belirlemek amacıyla yapılan araştırmada çocukların kendilerine sunulan hipotetik problem durumunda almış oldukları esneklik puanlarının yaşa göre farklılık gösterdiği sonucuna ulaşılmıştır. Elias, Rothbaum ve Gara (1986) tarafından yapılan araştırmada da 12 yaşındaki çocukların 9 yaşındaki çocuklara göre sosyal bilişsel problem çözme becerilerinde daha başarılı oldukları ortaya konmuştur. D’zurilla, Mydeu-Olivares ve Kant (1998) tarafından yaşları 17-80 arasında değişen yetişkinler üzerinde sosyal problem çözmede yaş ve cinsiyet farklılıklarını belirlemek amacıyla yapılan araştırmada sosyal problem çözme becerinin yaş ile birlikte artış gösterdiği doğrulanmıştır.

Araştırmadan elde edilen bir diğer bulgu ise sosyal problem çözme becerisinin cinsiyete göre anlamlı bir farklılık göstermediğidir. Cinsiyet farklılıklarının en çok vurgulandığı alanlar sosyal gelişim, iletişim, duygusal gelişim, davranış gibi etkileşim gerektiren alanlardır. Bu alanlar söz konusu olduğunda çoğunlukla kız ve erkek olma durumun göre belirgin bir farklılık olması beklenmektedir. Ancak son dönemde değişmeye ve gelişmeye devam eden toplum yapısı sebebiyle bu durum her zaman doğrulanan bir sonuç olmamaktadır. Daha önce de vurgulandığ1 gibi çocuklar artık kız ya da erkek ayrımı olmaksızın büyük çoğunlukla aynı çevre, eğitim, bilgiye ulaşım ve sosyalleşme deneyimi ve imkanlarına sahip olmaktadırlar. Bunun yanı sıra bu gelişme ve imkanlar doğrultusunda ebeveyn ve öğretmenlerin çocuğa karşı tutumlarında cinsiyet ayrımı gözeten davranışları da azalmaktadır. Bu durum geçmişten itibaren getirilen toplumsal cinsiyet rolleri arasındaki belirgin farklılığı kapatma eğilimindedir. Araştırmanın veri toplama işlemi sırasında çocuklarla yapılan birebir uygulamalarda erkek çocuklardan beklenilen agresif ya da kızlara göre daha saldırgan yanıtlar genel yargıda düşünülen şekilde kızlardan belirgin farklılık göstermemiştir. Bu durumun en önemli sebeplerinden birinin kız ve erkek çocuklarının okul öncesi eğitim kurumlarında aynı müfredatı, aynı ortamda almaları ve öğretmenlerin günlük yaşamda deneyimlenen sosyal yaşantılar konusunda çocukları bilinçlendirmeleri olduğu düşünülmektedir.

Sosyal problem çözme becerisinin cinsiyete göre farklılığına ilişkin literatür incelendiğinde cinsiyete göre farklılığın olmadığı sonucuna ulaşan ve cinsiyete göre farklılığın olduğunu vurgulayan farklı araştırmaların olduğu görülmektedir. Yılmaz (2012) tarafından 60-72 aylık çocukların duyguları anlama becerilerinin sosyal problem çözme becerilerine etkisini incelemek amacıyla yapılan araştırmada çocukların sosyal problem çözme becerilerinin cinsiyete göre anlamlı bir farklılık göstermediği sonucuna ulaşılmıştır. Benzer şekilde Dereli (2009) tarafından sosyal beceri eğitimi programının 6 yaş çocuklarının sosyal problem çözme 
becerilerine etkisini değerlendirmek amacıyla tapılan araştırmada çocukların sosyal problem çözme becerilerinin cinsiyete göre farklılaşmadığı görülmüştür. Rubin ve Krasnor (1983) tarafından okulöncesi ve anasınıfı çocuklarında hipotetik sosyal problemlerde yaş ve cinsiyet farklılıklarını belirlemek amacıyla yapılan araştırmada çocukların kendilerine sunulan hipotetik problem durumlarına vermiş oldukları cevaplar cinsiyete göre farklılık göstermemiştir. Yukarıda ifade edilen bu araştırmalar sosyal problem çözme becerisini ölçerken hem çocuğun vermiş olduğu cevabı prososyal ya da prososyal olmayan olarak değerlendirmiş hem de okulöncesi dönem çocukları üzerinde çalışmışlardır. Bunların yanı sıra literatürde sosyal problem çözme becerisinin cinsiyete göre farkl1lık göstermediğine ilişkin başka araştırmalar da yer almaktadır (Akbaş, 2005; Bal \& Temel, 2014; Chasse, 2004; Erwin, Firth, \& Purves, 2004; Y1lmaz \& Tepeli, 2013).

Sosyal problem çözme becerisine yönelik olarak yapılan araştırmaların bir kısmı bu araştırmada da olduğu gibi sosyal problem durumlarına verilen cevabın prososyal olması ya da prososyal olmaması ile ilgilenirken (Bal \& Temel, 2014; Dereli, 2009; Rubin \& Krasnor, 1983; Y1lmaz, 2012), bir kısmı bunun yanı sira sosyal problem durumlarına verilen cevapların sayısı ile ilgilenmişlerdir. Bu durumun sosyal problem çözme becerisinin cinsiyet değişkenine göre farklı sonuçlar elde edilmesinin bir sebebi olabileceği düşünülmektedir. Arı ve Yaban (2012), 9-11 yaş arası çocukların sosyal problem çözme becerilerinde cinsiyet ve yaş farklılıklarını belirlemek amacıyla yaptıkları araştırmada kızların sosyal problem durumlarına vermiş oldukları farklı cevap sayısının erkeklere göre daha fazla olduğu sonucuna ulaşmışlardır. Bu bulguyu literatürde yer alan diğer araştırmalar ile destelemişlerdir (Barbarasch, 1997; Crombie \& Gold, 1989). Sosyal problem çözme becerisinin cinsiyete göre farklı olduğu sonucuna ulaşan araştırmaların bir kısmının ise ergenlik ve yetişkinlik dönemi üzerinde yapılan araştırmalardan oluştuğu görülmektedir (Ar1 \& Yaban, 2012; Çam \& Tümkaya, 2006; D'Zurilla et al., 1998; Hamarta, 2007; Yaban \& Yükselen, 2007). Sosyal problem çözme becerisinin cinsiyet değişkenine göre farklılığını değerlendirirken birçok farklı parametrenin söz konusu olduğu ve bu parametrelere göre cinsiyete göre farklılık gösteren noktalar olduğu gibi farklılık göstermeyen noktaların da olduğu söylenebilir. Sonuç olarak okul öncesi dönemde çocukların sosyal problemlere vermiş olduğu cevabın niteliği (prososyal ya da prosoyal olmayan) bakımından cinsiyete göre farklılık görülmemektedir. Bunun yanı sıra cinsiyet farklılıkları çocukluk döneminden sonraki aşamada problemlere üretilen cevapların sayısı bakımından farklılaşmaktadır. $\mathrm{Bu}$ nedenle okul öncesi dönemde sosyal problem çözme becerisindeki 
cinsiyet farklılıklarını ortaya koymak amacıyla çocukların sosyal problemlere vermiş oldukları cevabın sayısını inceleyen araştırmalara ihtiyaç duyulmaktadır.

Sosyal problem çözme becerisine yönelik incelenen bir diğer değişken ise anne ve babanın yaşıdır. Araştırmadan elde edilen bulgulara göre çocuğun sosyal problem çözme becerisi anne ve babanın yaşına göre anlamlı bir farklılık göstermemektedir. Anne ve babanın yaşı ebeveynlik davranışı bakımından önem arz etmektedir. Çünkü anne ve babanın yaşı arttıkça edinmiş oldukları yaşam deneyimleri ve karakter anlamında olgunluk düzeylerinin artması beklenmektedir. Bu durum çocukların sosyal problem çözme bağlamında ilk örnekleri olan anne ve babasını zengin bir rol model kaynağı yapmaktadır. Ya da bir başka açıdan bakılacak olursa, genç anne ve babaların çocuk bakımı konusunda enerji ve sabırlarının daha yüksek olması çocuk bakımı açısından artı bir özellik olarak da değerlendirilebilir. Her iki açıdan da anne ve babanın yaşının önemli bir değişken olduğu anlaşılmaktadır. Ancak beklenildiği gibi araştırma sonucunda anne ve babanın yaşı çocuğun sosyal problem çözme becerisi üzerinde bir farklılığa sebep olmamıştır. Bu durumun sebebi anne ve baba yaşının tek başına çocuğun sosyal problem çözme becerisi üzerinde belirleyici olamamasından kaynaklanıyor olabilir. Anne ve babanın ebeveynlik davranışları tek başına yaş ile ilişkili değildir. Bireysel özellikler, eğitim durumu, çocukluk yaşantıları, çalışma durumu ve koşulları gibi birçok faktör anne ve babanın çocuğa sergilemiş olacağı sosyal problem çözme rol modellerinde belirleyici olabilir. Sosyal problem çözme becerilerine yönelik erişilebilen kaynaklar incelendiğinde anne ve baba yaşına ilişkin herhangi bir bulguya rastlanmamıştır.

Çocuğun sosyal problem çözme becerisini anne ve babanın eğitim durumuna göre farklılığ1 incelendiğinde anlamlı bir farklılık olmadığı görülmektedir. Bu durum çalışılan örneklem grubunun anne ve baba eğitim durumu dağılımından kaynaklanmış olabilir. Anne ve babanın eğitim durumunun dağılımına bakıldığında ortaokul ve öncesi ile lisansüstü eğitim durumuna sahip olan ebeveynlerin sayısı lise ve lisans eğitim durumuna sahip olan anne ve babalardan daha azdır. Bu nedenle muhtemel herhangi bir farkı istatistiksel olarak ortaya koymak mümkün olmamış olabilir. Çünkü anne ve babanın eğitim düzeyi birçok açıdan çocuğun gelişimi üzerinde önemli bir etkiye sahiptir. Eğitim düzeyi yüksek olan anne ve babanın; çocuğu ile olan iletişimi ve çocuğuna yönelik sosyalleştirme davranışlarının pozitif yönde farklı olacağı düşünülebilir. Kasik (2015) tarafından Macaristan'da bulunan 12 yaşındaki ergenler üzerinde iki yıl süre ile yapılan boylamsal araştırmada sosyal problem çözme becerisinin gelişimi incelenmiştir. $\mathrm{Bu}$ araştırma sonucunda anne ve babanın eğitim düzeyinin çocuğun sosyal problem çözme becerisi üzerinde etkili olduğu görülmüştür. Benzer şekilde Akbaş (2005) 
tarafından okul öncesi eğitime devam eden altı yaş grubu çocukların sosyal problem çözme becerilerinin incelenmesi amacıyla yapılan araştırmada, anne ve babaların eğitim durumları yükseldikçe çocukların sosyal problem çözme becerilerinin de arttığı ortaya konmuştur.

Anne ve babanın eğitim durumunun çocuğun sosyal problem çözme becerisi üzerindeki etkisini inceleyen araştırma sonuçlarındaki genel eğilim annenin eğitim durumunun çocuğun sosyal problem çözme becerisi üzerinde anlamlı bir farklılık yarattığı fakat babanın eğitim durumunun çocuğun sosyal problem çözme becerisi üzerinde anlamlı bir farklılık oluşturmadığ yönündedir. Yılmaz (2015) tarafından 60-72 aylık çocuklar üzerinde yapılan araştırmada, çocuğun sosyal problem çözme becerisinin annenin eğitim durumuna göre farklılaşırken babanın eğitim durumuna göre farklılaşmadığı ortaya koyulmuştur. Hamarta (2007) tarafından ilköğretim 8. sınıf öğrencileri ile yapılan araştırmada çocukların sosyal problem çözme becerilerinin annenin eğitim durumuna göre farklılaştı̆̆ fakat babanın eğitim durumuna göre ise farklılık göstermediği bulunmuştur. Arslan (2009) tarafından lise öğrencilerinin algılamış oldukları sosyal destek ile sosyal problem çözme becerileri arasındaki ilişkinin incelendiği araştırmada, anne eğitim durumu sosyal problem çözme becerisinde belirleyici olurken baba eğitim durumunun farklılı̆̆a sebep olmadığı belirlenmiştir.

Araştırma bulgularında çocuğun sosyal problem çözme becerisi anne ve baba çalışma durumu ve ailenin aylık gelir durumuna göre incelendiğinde, bu değişkenlerin göre çocuğun sosyal problem çözme becerisi üzerinde anlamlı bir farklılık oluşturmadığı görülmüştür. Çalışma durumu ve aylık gelir durumu ailenin sosyoekonomik düzeyini belirleyen önemli faktörlerdir. Literatür incelendiğinde anne ve babanın çalışma durumundan ziyade aylık gelir ya da sosyoekonomik düzey bağlamında çocuğun sosyal problem çözme becerisinin incelendiği görülmektedir. Çünkü, sosyo-ekonomik düzey ve aylık gelir durumu çocuğun sosyal problem çözme becerisi üzerinde önemli bir etkiye sahiptir (Akbaş, 2005; Bal \& Temel, 2014; Y1lmaz, 2012). Bu araştırma sonucunda söz konusu değişkenlere yönelik olarak farklılığın bulunmaması daha önce ifade edildiği gibi seçilmiş olan örneklem grubunun özelliklerinden kaynaklanıyor olabilir. Örneklem grubunun çalışma durumu, eğitim durumu ve aylık gelir durumuna bakıldığında; örneklem gurubunun çalışma durumu, eğitim durumu ve aylık gelir durumu bakımından benzer özelliklere sahip olduğu görülmektedir (Bkz.:Tablo 1). Bu durum sosyoekonomik düzey bakımdan olabilecek muhtemel farklılıkların ortaya konmasını sinırlandırmaktadır.

Sosyo-ekonomik düzey ve aylık gelir durumunun çocuğun sosyal problem çözme becerisi üzerindeki etkisini inceleyen araştırmalarda sosyal problem çözme becerisinin bu 
değişkenlerden etkilendiği kanısına varılmıştır. Bal ve Temel (2014) tarafından okul öncesi kurumlarına devam eden dört-altı yaş arası çocukların kişilerarası problem çözme ve bakış açısı alma becerilerini değerlendirmek amacıyla yapılan araştırmada sosyo-ekonomik düzey arttıkça çocuğun kişilerarası problem çözme becerisinin de artış gösterdiği görülmüştür. Benzer şekilde Akbaş (2005) ve Yılmaz (2012) tarafindan yapılan çalışmalarda aylık gelir durumunun çocuğun sosyal problem çözme becerisi üzerinde etkili olduğu sonucuna ulaş1lmıştır.

Son olarak bu çalışmada, sosyal problem çözme becerisinin kardeş sayısına göre farklılık gösterme durumu incelenmiş ve kardeş sayısına göre çocuğun sosyal problem çözme becerisinin anlamlı bir farkl11ık göstermediği görülmüştür. Bu durumun muhtemel iki sebebi olabilir. İlk olarak kardeş sayısı, tek çocuk olan çocuklara göre farklılığg ortaya koymakta oldukça önemli bir değişkendir. Bu araştırma kapsamında çocukların \%75,3'ünün ise kardeşi bulunmaktadır. Bu nedenle kardeş değişkenine ilişkin analizler söz konusu olabilecek farklılığ koymaya elverişli olmamış olabilir. Diğer bir sebep de örneklem grubunu oluşturan çocukların okul öncesi eğitim kurumuna devam eden çocuklar olması olabilir. Çocukların vakitlerinin büyük çoğunluğunu okul ortamında kendi akranları ya da kendilerinden büyük ve küçük çocuklar ile birlikte geçiriyor olmaları kardeş sayısının etkisini ortadan kaldırmış olabilir. Çocukların, kardeşleri olsun ya da olmasın okul ortamında birçok etkileşim fırsatı elde etmesi sebebiyle kardeş değişkeninin sosyal problem çözme becerisi üzerinde belirgin bir farklılığa yol açmadığı düşünülmektedir. Sosyal problem çözme becerisinde kardeş faktörünü inceleyen sınırlı sayıda araştırmaya rastlanmıştır. Bal ve Temel (2014) tarafindan okulöncesi dönem çocukları üzerinde yapılan araştırma bulguları bu araştırma sonucunu desteklerken Yılmaz ve Tepeli (2013) tarafindan 60-72 aylık çocuklar üzerinde yapılan araştırma sonucu farklılık göstermektedir. Yılmaz ve Tepeli (2013) tarafından yapılan araştırmada kardeşi olmayan çocuklar ile üç ve daha fazla kardeşi olan çocuklar arasında anlamlı bir farklılık bulunmuştur. Kardeşi olmayan çocukların sosyal problem çözme becerilerinin kardeşi olan çocuklardan daha yüksek olduğu görülmüştür. Y1lmaz ve Tepeli (2013) tarafindan elde edilen bu sonucun, bu araştırma bulgusundan farklılaşması araştırma kapsamında ele alınan çocukların büyük çoğunluğunun kardeşinin bulunması sebebiyle beklendik bir durumdur.

Daha önce ifade edildiği gibi sosyal problem çözme becerisi birçok açıdan çocukların ileriki yaşamdaki sosyal uyumlarının belirleyicisidir. Bu nedenle bu beceriye yönelik olarak yapılan çalışmaların arttırılması; çocukların, ebeveynlerin, öğretmenlerin ve müfredatın bu konu bakımından zenginleştirilmesi önerilmektedir. Ebeveynler ve okul öncesi eğitime başlama ile birlikte çocukların hayatında önemli bir yer edinmeye başlayan öğretmenlerin, günlük yaşam 
becerileri içerisinde doğal yollarla sosyal problem çözme pratikleri ile çocuğa rol model olmaları, bu becerinin gelişiminde kritik bir öneme sahiptir. Özellikle sosyal problem çözme becerilerinin temelinin atıldı̆̆ okul öncesi dönemin kritik bir dönem olduğu göz önünde bulundurularak, bu dönemde çocukların hangi yollarla geliştirilebileceğinin incelenmesi, aile ve çocuk eğitim programlarının geliştirilmesi önerilmektedir. Konu ile ilgili olarak daha sonra yapılacak olan araştırmaların daha geniş ve farklı ekonomik düzeylerden oluşan örneklem gruplarında yapılması ve çocukların hipotetik problem durumlarına vermiş oldukları yanıtların gerçek yaşamda nasıl uygulandığına ilişkin gözlemsel tekniklerle desteklenerek yapılması önerilmektedir.

\section{KAYNAKÇA}

Akbaş, S. C. (2005). Okul öncesi eğitime devam eden altı yaş grubu çocukların sosyal problem çözme becerilerinin incelenmesi. Yayımlanmamış Yüksek Lisans Tezi.

Anliak, Ş., \& Dinçer, Ç. (2005). The Evaluation of the Interpersonal Problem Solving Skills of the Children Attending to the Preschools Applying Different Educational Approaches. Ankara University, Journal of the Faculty of Educational Sciences, 38, 149-166.

Arı, M., \& Yaban, H. (2012). 9-11 yaşındaki çocukların sosyal problem çözme becerilerinde cinsiyet ve yaş farklılıkları. Ë̆itim ve Bilim, 37(164).

Arslan, Y. (2009). Lise öğrencilerinin algıladıkları sosyal destek ile sosyal problem çözme arasındaki ilişsinin incelenmesi. (Yayımlanmamış Yüksek Lisans Tezi), Konya Selçuk Üniversitesi, Konya.

Bal, Ö., \& Temel, Z. F. (2014). Okul öncesi eğitim kurumlarına devam eden 4-6 yaş çocuklarının kişiler arası problem çözme ve bakış açısı alma becerileri arasındaki ilişsinin incelenmesi. Trakya Üniversitesi Eğitim Fakültesi Dergisi, 4(1).

Barbarasch, B. S. (1997). The effect of parenting style and social problem solving thinking skills on sixth graders' adaptation to middle school: publisher not identified.

Büyüköztürk, Ş., Çakmak, E. K., Akgün, Ö. E., Karadeniz, Ş., \& Demirel, F. (2008). Bilimsel araştırma yöntemleri. Ankara: Pegem Akademi, 177-184.

Casey, M. B. (1990). A planning and problem-solving preschool model: The methodology of being a good learner. Early Childhood Research Quarterly, 5(1), 53-67.

Cartıllı, K. \& Bedel, A. (2015). Sosyal Problem Çözme Beceri Eğitiminin Annelerin Sosyal Problem Çözme ve Çocuk İlişkisine Etkisi. Türk Psikolojik Danışma ve Rehberlik Dergisi, 5(43).

Chasse, K. (2004). Individual and family factors that influence the social problem solving skills of inner city African American pre-adolescents. Unpublished master of art thesis, Columbia University, USA.

Chen, X., \& Rubin, K. H. (1992). Correlates of peer acceptance in a Chinese sample of sixyear-olds. International Journal of Behavioral Development, 15(2), 259-273.

Crombie, G., \& Gold, D. (1989). Compliance and problem-solving competence in girls and boys. The Journal of genetic psychology, 150(3), 281-291. 
Çam, S., \& Tümkaya, S. (2006). Üniversite öğrencilerinde kişilerarası problem çözme. Çukurova Üniversitesi Sosyal Bilimler Enstitüsü Dergisi, 15(2), 119-132.

D'zurilla, T. J., \& Goldfried, M. R. (1971). Problem solving and behavior modification. Journal of abnormal psychology, 78(1), 107.

D'Zurilla, T. J., \& Maydeu-Olivares, A. (1995). Conceptual and methodological issues in social problem-solving assessment. Behavior Therapy, 26(3), 409-432.

D'Zurilla, T. J., Maydeu-Olivares, A., \& Kant, G. L. (1998). Age and gender differences in social problem-solving ability. Personality and individual differences, 25(2), 241-252.

D'Zurilla, T. J., \& Nezu, A. M. (1999). Problem-solving therapy: A social competence approach to clinical intervention: Springer Publishing Company.

D'Zurilla, T. J., Nezu, A. M., \& Maydeu-Olivares, A. (2004). Social Problem Solving: Theory and Assessment.

Dereli-İman, E. (2013). Çocuklar için Sosyal Problem Çözme Ölçeği’nin 6 yaş grubu için Türkiye uyarlaması ve okul öncesi davranış problemleri ile sosyal problem çözme becerileri arasındaki ilişkiler. Kuram ve Uygulamada Ĕgitim Bilimleri, 13, 491-498.

Dereli, E. (2009). Examining the permanence of the effect of a social skills training program for the acquisition of social problem-solving skills. Social Behavior and Personality: an international journal, 37(10), 1419-1427.

Elias, M. J., Rothbaum, P. A., \& Gara, M. (1986). Social-cognitive problem solving in children: Assessing the knowledge and application of skills. Journal of applied developmental psychology, 7(1), 77-94.

Erwin, P. G., Firth, K., \& Purves, D. G. (2004). Task characteristics and performance in interpersonal cognitive problem solving. The Journal of psychology, 138(2), 185-192.

Feis, C. L., \& Simons, C. (1985). Training preschool children in interpersonal cognitive problem-solving skills: A replication. Prevention in Human Services, 3(4), 59-70.

Field, A. (2009). Discovering statistics using SPSS: Sage publications.

Gesten, E. L., Flores de Apodaca, R., Rains, M., \& Weissberg, R. P. (1979). Promoting peer related social competence in young children. Primary prevention of psychopathology, Vol. 3. Promoting social competence and coping in children; Hanover, NH: University Press of New England, 220.

Gülay, H., \& Akman, B. (2009). Okul öncesi dönemde sosyal beceriler. Ankara: Pegem Akademi Yayınları.

Güneysu, S., Dinçer, Ç., \& Etikan, İ. (1997). 54-78 aylık çocukların kişiler arası problemlere getirdikleri çözümleri etkileyen faktörler. Paper presented at the I. National Child Development and Education Congress 28.

Hamarta, S. (2007). İlköğretim 8. sınıf öğrencilerinin sosyal problem çözme becerilerinin algılanan anne-baba tutumları açısından incelenmesi. Yüksek Lisans Tezi (Yayınlanmamış), Selçuk Üniversitesi Sosyal Bilimler Enstitüsü, Konya.[In Turkish].

Israel, G. D. (1992). Determining sample size: University of Florida Cooperative Extension Service. Institute of Food and Agriculture Sciences, EDIS. 
Kasik, L. (2015). Development of social problem solving - A longitudinal study (2009-2011) in a Hungarian context. European Journal of Developmental Psychology, 12(2), 142157.

Kayılı, G., \& Arı, R. (2015). Wally sosyal problem çözme testi: geçerlik ve güvenirlik çalişmasi. Uluslararası Eğitim Bilimleri Dergisi / The Journal of International Education Science, 3(2), 51-60.

Keltikangas-Järvinen L. (2005) Social problem solving and the development of aggression. Social problem solving and offending: Evidence, evaluation and evolution. John Wiley \& Sons, Ltd. 31-49.

Nelson-Le Gall, S. (1981). Help-seeking: An understudied problem-solving skill in children. Developmental Review, 1(3), 224-246.

Pakaslahti L, Karjalainen A, Keltikangas-Järvinen L. (2002) Relationships between adolescent prosocial problem-solving strategies, prosocial behaviour, and social acceptance. International Journal of Behavioral Development., 26(2):137- 44.

Paswan, S., Sanjeev, K., \& Bansal, I. (2014). Peer Ratings and Social Problem-solving Skills of 6-8 Years Old Children.

Perez V, Gesten EL, Cowen EL, Weissberg RP, Rapkin B, Boike M. (1981). Relationships between family background problems and social problem solving skills of young normal children. Journal of Primary Prevention, 2(2):80- 90.

Ridley, C. A., \& Vaughn, S. R. (1982). Interpersonal problem solving: An intervention program for preschool children. Journal of Applied Developmental Psychology, 3(3), 177-190.

Rooney EF, Poe E, Drescher D, Frantz SC. (1993). I can problem solve: An interpersonal cognitive problem-solving program. Journal of School Psychology, 31(2):335-9.

Rubin, K. H., Daniels-Beirness, T., \& Bream, L. (1984). Social isolation and social problem solving: A longitudinal study. Journal of Consulting and Clinical Psychology, 52(1), 17.

Rubin, K. H., \& Krasnor, L. R. (1983). Age and gender differences in solutions to hypothetical social problems. Journal of applied developmental psychology, 4(3), 263-275.

Rubin, K. H., \& Krasnor, L. R. (1986). Social-cognitive and social behavioral perspectives on problem solving. Paper presented at the Cognitive perspectives on children's social and behavioral development. The Minnesota Symposia on Child Psychology.

San Bayhan, P., \& Artan, İ. (2004). Çocuk gelişimi ve eğitimi: Morpa Kültür Yayınları.

Sharp, K. C. (1981). Impact of interpersonal problem-solving training on preschoolers' social competency. Journal of Applied Developmental Psychology, 2(2), 129-143.

Shure, M. B. (2001). I can problem solve (ICPS): An interpersonal cognitive problem solving program for children. Residential Treatment for Children \& Youth, 18(3), 3-14.

Shure, M. B., \& Spivack, G. (1979). Interpersonal cognitive problem solving and primary prevention: Programming for preschool and kindergarten children 1. Journal of Clinical Child \& Adolescent Psychology, 8(2), 89-94. 
Shure, M. B., \& Spivack, G. (1982). Interpersonal problem-solving in young children: A cognitive approach to prevention. American Journal of Community Psychology, 10(3), 341-356.

Spivack G, Shure MB. (1974). Social adjustment of young children. San Francisco: JosseyBass.

Spivack, G., \& Shure, M. B. (1985). ICPS and beyond: Centripetal and centrifugal forces. American Journal of Community Psychology, 13(3), 226.

Spivack G, Shure MB. Interpersonal cognitive problem solving (ICPS): A competence-building primary prevention program. Journal of Prevention \& Intervention in the Community. 1989;6(2):151-78.

Webster-Stratton, C. (1990). Dina dinosaur's social skills and problem-solving curriculum. Seattle, WA, 1411.

Yaban, E. H., \& Yükselen, A. (2007). Korunmaya Muhtaç Yedi-On Bir Yaş grubundaki Çocukların Sosyal Problem Çözme Becerilerinin incelenmesi Journal of Society \& Social Work, 18(1).

Yılmaz, E. (2012). 60-72 aylık çocukların duyguları anlama becerilerinin sosyal problem çözme becerilerine etkisinin incelenmesi. Selçuk Üniversitesi Sosyal Bilimler Enstitüsü.

Yılmaz, E., \& Tepeli, K. (2013). 60-72 Aylik Çocuklarin Sosyal Problem Çözme Becerilerinin Duygulari Anlama Becerileri Açisindan Incelenmesi. Türkiye Sosyal Araştırmalar Dergisi, 172(172), 117-130. 